\title{
Role and Impact of Non-governmental Organizations: The Case Study of 'Free Lunch for Children' In China
}

\author{
$\mathrm{Xi} \mathrm{Xi}^{1,2}$, Farhad Hossain ${ }^{3}$ \\ ${ }^{1}$ Institute for Development Policy and Management, the University of Manchester, Manchester, \\ United Kingdom; \\ ${ }^{2}$ Morgan Philips Executive Search, Shanghai, China; \\ ${ }^{3}$ Institute for Development Policy and Management, the University of Manchester, Manchester, \\ United Kingdom \\ xixisnnu@163.com
}

Keywords: NGO; government policy; Flee Lunch for Children; Nutritional Supplement Plan.

\begin{abstract}
During the last two decades, non-governmental organizations have come to be important actors in development and poverty reduction at local, national and global levels. This trend has spread all over the world. Since the reform and opening up in 1978, China has experienced dramatic changes, many grassroots NGOs have arisen to seek alternative approaches to solve development problems by delivering basic services and some of them begin to campaign policy advocacy. Inevitably, it affects China and Chinese society. The aim of this paper is to identify the roles and impacts of non-governmental organizations in development, focusing on the Chinese grassroots NGOs' contributions in filling in governance blanks and shaping government policy by the case study of 'Free Lunch for Children' In China.
\end{abstract}

\section{Introduction}

The term NGOs (non-governmental organizations) is generally understood by public as a group of people or organizations that engaged in reducing poverty and helping people in need. However, the definition of NGOs is various by different authors, organizations, sectors and regions. Among a variety of definitions, this paper will use the one by Vail (1997) that defines NGOs as 'self-governing, private, not-for-profit organizations that are geared to improving the quality of life of disadvantaged people'. This definition offers a clear view of key factors of NGOs and also fits well in the aim, theories and case of this article.

During the last two decades, non-governmental organizations have come to be important actors in development and poverty reduction at local, national and global levels. This trend has spread all over the world. 'The acronym NGO has become part of everyday language in many countries.' (Lewis \& Kanji, 2009). Since the reform and opening up in 1978, China has experienced dramatic changes, many grassroots NGOs have arisen to seek alternative approaches to solve development problems by delivering basic services and some of them begin to campaign policy advocacy. Inevitably, it affects China and Chinese society.

The aim of this paper is to identify the roles and impacts of non-governmental organizations in development, focusing on the Chinese grassroots NGOs' contributions in filling in governance blanks and shaping government policy.

\section{The Roles of NGOs}

Lewis (2001) identifies the service delivery role and the catalyst role of NGOs. He also categorizes the catalyst role in his further research. 'One form of catalyst is the NGO that aims to bring about change through advocacy and seeking influence; another is the NGO that aims to innovate and apply new solutions to development problems' (Lewis, 2009). Moreover, Lewis (2001) points the partnership role, which is the growing trend that NGOs work with other organizations, including government, private sector, donors, other NGOs and also between countries. To solve development 
problems and make a difference, the power of one NGO is insufficient. Partnership offers access to external resources and information. Over above three roles, Lewis (2009) also emphasizes that, in most practical cases, NGOs are engaged in multiple roles and activities.

Although the theories of Kurten and Lewis are elaborated in different terms and approaches, some common features of NGOs roles can be concluded. In development, NGOs start from simple, even small, efforts in meeting immediate deficiencies, and then seek to sustainable, larger scale and powerful contributions and changes.

\section{The Relationship between Government and NGOs}

The relationship between government and NGOs is complex. On the one hand, this relationship is not optimistic. 'There is often a mutual distrust between NGOs and governments.' (Clark, 1992) It is widely accepted that NGOs are created as a response to government failure in meet people's demands for public or semi-public goods (Hansmann, 1980; Seibel \& Anheier, 1990; Aminuzzaman, 1998; Suavely \& Desai, 2001). NGOs fill in the gap in government service, which, to some extent, shows citizens the incompetence of authorities. Since private institutional initiatives can challenge the state's legitimacy or undermine its power base, 'NGOs may indeed be perceived by government as a threat or as competitors.' (Lewis, 2001)

On the other hand, as NGOs have the partnership role, 'the nature of cross-sector interaction is not uniform' (Najam, 2000). Grodland (2008) suggests that NGOs not only provide assistance but also engage in various types of collaboration. For example, 'local governments and NGOs often collaborate in a variety of ways such as joining forces to deliver social welfare services, sharing personnel and financial resources, engaging in policy dialogue, and cooperating in training programs.' (suavely \& Desai, 2001)

Conflicts and collaborations are coexisting between government and NGOs. Bratton (1989) suggests that 'government-NGO relations are likely to be most constructive where a confident and capable government with populist policies meets an NGO that works to pursue mainstream development programs.'

\section{Impact of NGOs}

By delivering services, campaigning advocacy and cooperating with other organizations, NGOs have had significant impacts on individual, social, national and global levels. However, an NGO is not a panacea. As a corn has two sides, an NGO has its positive and negative impacts.

Positive. According to numerous achievements in NGOs practice, the positive impacts of NGOs can be categorized into following aspects.

Offer A New Approach To Solve Problems. Between market and state, NGOs offer a new channel for development aid. NGOs notice and try to help individuals, families and regions which are ignored or unsatisfied by government and market, filling in the blank of governance. Regardless of policy and money, there is another possibility to solve development problems, which gives hope for people in need and the society.

Meet Needs More Effectively. The approaches that NGOs offered are better than measures took by other organizations. Embedded in local life and culture, NGOs, especially grassroots NGOs, can identify immediate needs of local people to offer direct goods and services. Anheier (1990) points four comparative advantages of NGOs that are stimulating participation of the poor, more economically; more honest and more sensitive to local needs from social, economic, political and cultural aspects.

Keep Policy Honest. Najam (1999) suggests that NGOs can keep policy honest. This not only means that NGOs can act as whistleblowers to exam the rationality of exist shape of new policies. NGOs, as the third sector, are more powerful than a single individual or family and stand on a more objective position; therefore they can influence policies more effectively.

Negative. Besides flowers and applause, NGOs do not always result in positive impacts. There are some criticisms towards the impacts of NGOs. 
No Sustainable Measures. Lewis (2001) summarizes that 'NGOs and their groups do not constitute real movements of the poor, but are simply of people brought together around provision of resources'. Although service delivery is the basic role of NGOs, if they do not explore local people's capacities and build up a sustainable development model, once the resources are no longer available, local people will be left and return to poverty. Moreover, the goods and services deliveries by NGOs can keep local people live just above the poverty line, which may be a palliative that reduce the willingness of people to take actions and purse higher level of life (Arellano-Lopez \& Petra's, 1994).

Transferring Western concept. In China NGOs and their missions are influenced by their donors, who are always from Western countries. This means NGOs will intentionally or unintentionally transfer Western value, which may strike local traditional culture and lifestyle and harm the interests of the poor. Earle (2005) suggests that NGOs reduce state role in welfare provision by transferring neo-liberalism. This trend shifts the poverty reduction attention and accountability from local government to NGOs (Kang, 2001).

After examine pros and cons of NGOs, the FLFC case will demonstrate the roles and impacts of a grassroots NGO in contemporary China.

\section{Case Study-Free Lunch for Children (FLFC) in China}

Some influential NGOs have set up in China, including One Foundation, Friends Of Nature, Smile Angel Foundation, the Society of Entrepreneurs and Ecology, etc... Free Lunch for Children is also one of them.

Free Lunch for Children (FLFC). FLFC is a charity project founded by a journalist Deng Fei to sponsor free diets for poverty-stricken school children in China by public micro-donations.

In early 2011, When Deng Fei, a journalist of Phoenix Weekly Magazine, learned from a volunteer teacher named Xiaoyu from Guizhou Province that most of children in primary schools of rural areas did not have any food for lunch because they could not afford lunch or there were no canteens in schools. After visiting several schools, Deng found that the real situation was even worse. Starvation became part of those children's life and seriously affected their mental and physical health. Shocked by the cruel facts, Deng and his colleagues began raising money online through Weibo (China's Twitter-like service) and Taobao (an online shopping site) from public, soliciting micro-donations of food for only 3 yuan (less than 30 pence) per lunch. With this money, children can have lunch with meat, vegetables, eggs, soup and rice cooked in school canteen. For most of these impoverished kids, this is their best meal of the day. FLFC also works with several local authorities. Besides helping FLFC volunteers monitor donations in schools, local governments contribute funds and help to target poorer schools. For example, in Hujiaying school, local government provided 1 million yuan $(£ 10,000)$ to build school canteen.

After FLFC formally founded, Deng entrusted the China Social Welfare Foundation to professionally operate donations. Every donation can be checked on FLFC website and FLFC also posts its weekly expense reports online. Each Free Luch school is required to open up a Weibo account to post detailed information including expenses, daily meal and feedback from students. FLFC aperiodically delegates volunteers to spot check and monitor schools' implementations. According to its 2012 financial report, FLFC received 43,773,583.75 RMB yuan (about 4.4 million GBP) from public donations, from April 2011 to December 2012. There are 36467 students from 205 schools in 17 provinces benefit from this project in 2012. Moreover, FLFC is growing rapidly and tries to cover more students and schools. Compared with the number of students benefited in 2011 , the growth rate is $136 \%$.

On October 26th, 2011, 6 months after the foundation and success of FLFC, Chinese central government announced to implement the Nutritional Supplement Plan (NSP) in rural compulsory education schools. This project also aims to offer free lunch for rural primary and secondary school students, working on the FLFC standard as 3 yuan per meal. On June 6th, 2012, NSP also required each school post its daily meal through Weibo. Deng said 'We can't say that our Free Lunch has directly led to the government's Free Lunch, but there's a link.' 
Government Participation: NSP. Central government required national finance allocate about 16 billion RMB to support NSP and it could cover 680 counties and 26 million students. The Chinese central government does not formulate official implementation measures but it empowers local governments and schools to create and choose their most suitable patterns.

There are some good examples that the Ministry Of Education considers worth spreading and posts on its website. Building canteen. As most rural schools do not have canteens, several local governments (Bijie, Guizhou; Ziyang, Sichuan) allocate money to solve this problem. Some local finances (Liuzhou, Guangxi; Huichang, Jiangxi; Cuiping, Yibin) also pay salaries of cooks and offer nutrition trainings. Outsourcing. Some local governments (Dushan, Guizhou; Yanting, Sichuan) outsource the task of offering lunch to food companies through public bidding. Employ inspectors. In order to monitor schools' implementation, several governments (Ningdu, Jiangxi; Yanting, Sichuan) employed full-time inspectors. Some governments (Guangyuan, Sichuan; Langao, Shaanxi) let teachers, students and retired staffs record quality and quantity of lunch. Headmaster escort. To ensure the safety of supplied food, headmasters are required to have the same lunch with students in some areas (Guyuan, Ningxia). Some local governments believe that if headmaster has to eat with students, he or she would treat the quality of food more seriously, therefore can ensure students' services.

Since implementation from the end of 2011, NSP has benefited many rural students. However, there are several problems. 'Shrinkage' is one of them. On October 30, 2011, a volunteer teacher Liang exposed on Weibo that the students' lunch offered by government was only a small piece of biscuit, which worthed less than 0.5 yuan ( 5 pence). After investigation, this was resulted from corruption. In some areas, schools and governments count other costs such as transportation, storage and processing of food in the 3-yuan-standard, which means the meal for students, will be less. Food safety is another serious problem. Students in many areas (Xuanwei, Yunan; Napo,Guangxi; Bijie, Guizhou) experienced food poisoning after eating government offered lunch.

\section{Findings and Analysis.}

Comparison between FLFC and NSP. Both FLFC and NSP aim to offer free lunch for impoverished children at a standard of 3 yuan per meal and started from 2011, but NSP started 6 months later than FLFC. There are some similarities and differences between them.

Coverage. Both of them offer free diets for primary schools of rural areas to improve the student's life. FLFC got the needed money by public micro-donations, while,NSP based on strong national financial support, covers 26 million students, which is far more than 36 thousand students of FLFC. It is a good result that much more students benefit from the active-Free Lunch.

Financial Transparency. As a grassroots organization receiving public donations, FLFC publishes weekly expense and annual finance report online through Weibo and its website. NSP reports its financial situation as a part of people's livelihood subsidy in local government annual financial report only through government internal system.

Standard. Although both FLFC and NSP announce to apply the 3 yuan standard, the actual food eaten by students is different. FLFC offers a warm full meal with meat, vegetables, egg, soup and rice. Some schools of NSP also offer meal with vegetables and rice while others just provide bread or biscuit.

Supervision. FLFC delegates volunteers and invites local government officials to check and monitor expense implementations in schools. Donations to FLFC are operated by China Social Welfare Foundation. NSP supervises schools through inspectors and headmasters. The money allocated from national finance is monitored by local governments themselves.

Other Aspects. Local government has the right to give some place to build canteens and employ special cooks and offer nutrition trainings.

From above comparison, the strengths and weaknesses of FLFC and NSP can be concluded. NSP has more resources than FLFC to solve starvation of children while FLFC is more efficient and effective than NSP in delivering food and services. 
Roles and Impacts of FLFC. From above profile, FLFC starts because of Deng's observation of governance gap. To solve the urgent starvation problem, some simple direct actions, such as building canteens and sending food, are taken. It is obvious that FLFC acts the delivery role. Building good cooperation relationship with some local government, FLFC also acts the partnership role. With small but continuous endeavor, FLFC meets the need of those poor children and also creates new approach and standard to give help. Moreover, influenced by FLFC, central government publishes new policy, the NSP, to solve the issue that it ignored before. FLFC being as catalyst and 'pilot' provides government a good example to apply and spread. In this way, FLFC shapes new policy and keeps policy honest. However, if FLFC and central government can cooperate with each other and therefore carry forward advantages of both sides, the children starvation can be wiped out more effectively nationwide.

The FLFC case provides a good example of roles and impacts of NGOs. In the FLFC case, the service delivery role, catalyst role and partnership role, and positive impacts, such as create new approach, meet needs and influence policy, of NGOs are illustrated clearly.

\section{Conclusion}

NGOs can act many roles (service delivery, catalyst and partnership) and have numerous positive impacts in development. However, a single NGO cannot eliminate nationwide problems. By delivering services, campaigning advocacy and cooperating with other organizations, NGOs have a complex relationship with government, which means conflicts and collaborations are coexist. NGOs create a better approach for development aid and can sharp policies. It influenced government policy, directly or indirectly, in offering free lunch for rural students. In order to seek benefits and avoid damages, NGOs should scale up its successful strategies by collaborating with other organizations and government, while the government should give some support to NGOs in order to better meet the people's needs in their life.

\section{Reference}

[1] Aminuzzaman, S. (1998), 'NGOs and the grassroots base local government in Bangladesh: a study of their institutional interactions', in NGOs under challenge, dynamics and drawbacks in development, Malkia, M. \& Hossain, F. (Ed.), Helsinki: Ministry for Foreign Affairs, Dept. for International Development Cooperation, pp. 84-104

[2] Anheier, H. K. (1990), 'Private voluntary organizations and the third world: the case of Africa', in The Third sector: comparative studies of nonprofit organization, Anheier, H. K. \& Seibel,W (Ed.), Berlin : Walter de Gruyter 1990, pp. 361-373

[3] Arellanolopez, S \& Petra's, J. F. (1994), 'Nongovernmental organizations and poverty alleviation in Bolivia', Development and change, Vol.25 (3), pp.555-568

[4] Bratton,M. (1989), 'The politics of NGO-government relations in Africa', World development, Vol. 17(4), pp. 569-87

[5] Clark, J (1992), 'Democratizing', Development in Practice, Vol.2(3), pp.151-162

[6] Earle, L. (2005), 'Community Development, Tradition and the Civil Society Strengthening Agenda in Central Asia', Central Asian Survey, Vol. 24(3), pp. 245-60.

[7] Hangman, H. B. (1980), 'The Role of Nonprofit Enterprise', The Yale Law Journal, Vol.89(5), pp.835-901

[8] Groveland, A.B. (2008), 'Suspiciously supportive or suspiciously obstructive? - The relationship between local governmentand NGOs in Bosnia and Herzegovina, Serbia, and Macedonia', International Journal of Public Administration, Vol.31 (8), pp.911-952 
[9] Kang, J. (2011), 'Understanding non-governmental organizations in community development: Strengths, limitations and suggestions', International Social Work, Vol.54(2), pp.223-237

[10]Lewis, D. \& Kanji, N. (2009), Non-governmental organizations and development, London : Routledge

[11]Lewis,D. (2001), The management of non-governmental development organizations : an introduction, London : Routledge

[12] Najam, A. (1999) 'Citizen Organization as policy entrepreneurs'. In International Perspectives on Voluntary Action:Reshaping the Third Sector, D. Lewis (ed.), London: Earthscan, pp.142-181

[13] Najam, A. (2000), 'The four C's of government third sector-government relations', Nonprofit management and leadership, Vol. 10(4), pp. 375-396

[14] Official website of FLFC, available at:http://www.mianfeiwucan.org/ (Accessed: 7th , 2013)

[15] Official website of NSP, available at:

http://www.moe.gov.cn/publicfiles/business/htmlfiles/moe/s6329/list.html (Accessed: 7th, December 2013).

[16] Photos about FLFC, available at:

http://www.ministryoftofu.com/2011/09/photos-lunch-is-a-luxury-for-chinas-rural-children-and -you-can-help-them/ (Accessed: 7th, December 2013)

[17] Report about FLFC, available at :

http://en.chinagate.cn/archives/povertyprojects/2013-04/08/content_28478901.htm (Accessed: 7th, December 2013)

[18] Snavely, K. \& Desai, U. (2001), 'Municipal Government-Nonprofit Sector Collaboration in Bulgaria: An Attitudinal Analysis', The American Review of Public Administration, Vol. 31 (1), pp. 31-49

[19] Snavely, K. \& Desai,U. (2001), 'Mapping local government-nongovernmental organization interactions: a conceptual framework', Journal of Public Administration Research and Theory, Vol.11(2), pp. 245-263

[20] The World Bank's China Overview. Available at: http://www.worldbank.org/en/country/china/overview (Accessed: 7th, December 2013).

[21] Vakil, AC. (1997), 'Confronting the classification problem: Toward a taxonomy of NGOs', World Development, Vol.25(12), pp.2057-2070

\section{Author Brief and Sponsors or Supporters.}

$\mathrm{Xi} \mathrm{Xi,} \mathrm{Female,Graduated} \mathrm{from} \mathrm{The} \mathrm{University} \mathrm{of} \mathrm{Manchester,} \mathrm{working} \mathrm{as} \mathrm{Search} \mathrm{Consultant} \mathrm{in}$ Morgan Philips Executive Search, E-mail: xixisnnu@163.com 